\title{
South Georgia and the South Sandwich Islands
}

National Cancer Institute

\section{Source}

National Cancer Institute. South Georgia and the South Sandwich Islands. NCI Thesaurus.

Code C20111.

A group of islands in the South Atlantic Ocean, east of the Falkland Islands. 